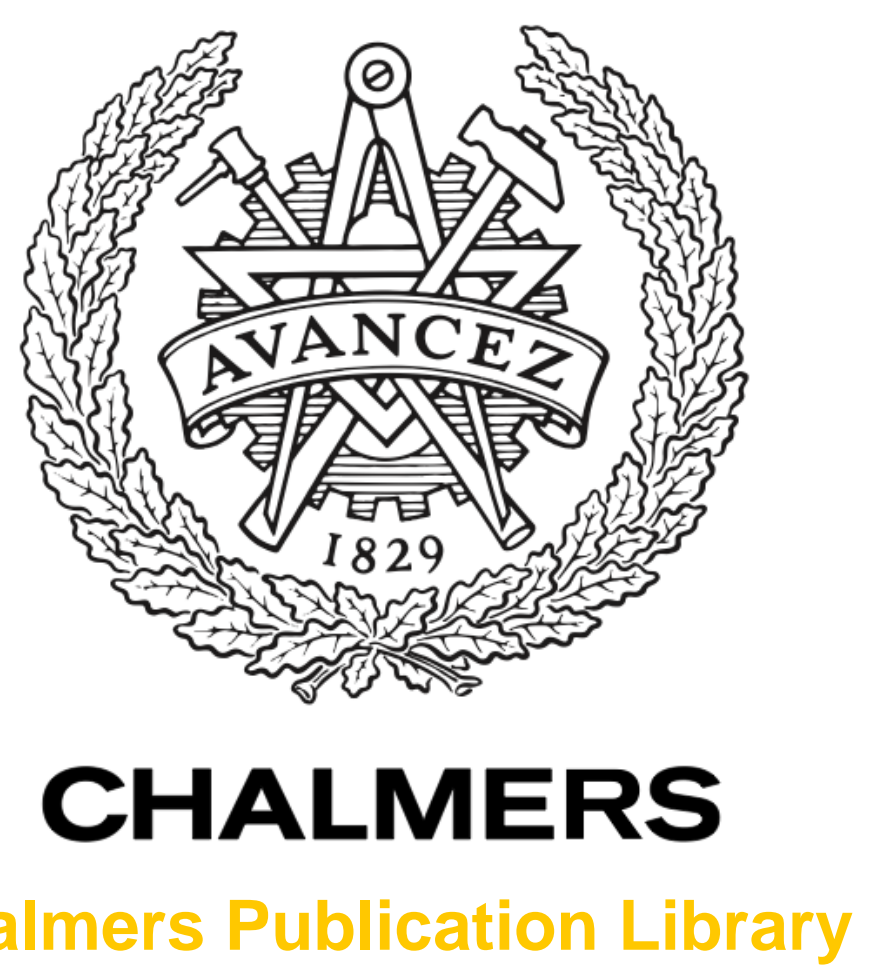

Chalmers Publication Library

\author{
Abuse by External Heating, Overcharge and Short Circuiting of Commercial \\ Lithium-Ion Battery Cells
}

This document has been downloaded from Chalmers Publication Library (CPL). It is the author's version of a work that was accepted for publication in:

Journal of the Electrochemical Society (ISSN: 0013-4651)

Citation for the published paper:

Larsson, F. ; Mellander, B. (2014) "Abuse by External Heating, Overcharge and Short Circuiting of Commercial Lithium-Ion Battery Cells". Journal of the Electrochemical

Society, vol. 161(10), pp. A1611-A1617.

http://dx.doi.org/10.1149/2.0311410jes

Downloaded from: http://publications.lib.chalmers.se/publication/202190

Notice: Changes introduced as a result of publishing processes such as copy-editing and formatting may not be reflected in this document. For a definitive version of this work, please refer to the published source. Please note that access to the published version might require a subscription.

Chalmers Publication Library (CPL) offers the possibility of retrieving research publications produced at Chalmers University of Technology. It covers all types of publications: articles, dissertations, licentiate theses, masters theses, conference papers, reports etc. Since 2006 it is the official tool for Chalmers official publication statistics. To ensure that Chalmers research results are disseminated as widely as possible, an Open Access Policy has been adopted.

The CPL service is administrated and maintained by Chalmers Library. 


\title{
Abuse by External Heating, Overcharge and Short Circuiting of Commercial Lithium-Ion Battery Cells
}

\author{
Fredrik Larsson $^{\mathrm{a}, \mathrm{b}, \mathrm{z}}$ and Bengt-Erik Mellander ${ }^{\mathrm{a}}$ \\ ${ }^{a}$ Department of Applied Physics, Chalmers University of Technology, Goteborg SE-412 96, Sweden \\ ${ }^{b}$ SP Technical Research Institute of Sweden, Boras SE-501 15, Sweden
}

\begin{abstract}
Lithium-ion batteries offer great energy and power densities but the thermal stability is an issue of concern compared to other battery technologies. In this study different types of abuse testing have been performed in order to compare the battery safety for different types of commercial lithium-ion battery cells. The results show large differences in abuse response for different cells. Exposed to external heating laptop cells with cobalt based cathode developed a thermal runaway resulting in pressure release, fire and temperatures over $700^{\circ} \mathrm{C}$. Lithium iron phosphate (LFP) is known to be a very thermally stable cathode material and LFP-cells showed a significantly lower thermal response, a thermal runaway could, however, be detected for some of the cells in the external heating test. The overcharge tests of LFP-cells were in most cases uneventful but in one case the test resulted in a violent fire. The short circuit tests showed modest temperature increases of the cells in spite of high currents peaking at around 1000 A. Although the development of safer lithium-ion battery cells has been successful thermal runaway events may still occur under extreme conditions. (C) 2014 The Electrochemical Society. [DOI: 10.1149/2.0311410jes] All rights reserved.
\end{abstract}

Manuscript submitted April 28, 2014; revised manuscript received June 4, 2014. Published July 11, 2014.

The high energy and power density of lithium-ion batteries have made them the preferred type of battery for battery electric vehicles as well as for plug-in hybrid electric vehicles. Lithium-ion batteries have many advantages but the reactive, volatile and flammable materials present in the battery are a concern and may be a threat to safety. Lithium-ion batteries are produced in large quantities, mainly for small consumer products such as cellular telephones and other portable electronic devices. Using them in electric vehicles poses another situation since the large size of the battery as well as the environmental conditions that the battery is exposed to in terms of temperature, vibrations etc have an influence on the safety. In addition, requirements such as long life time and the possibility for a fast recharge of the battery calls for other demands on the cells. All these aspects have an effect on the safety of the vehicle, including the safety for people inside and outside the vehicle, for service personnel involved in maintenance and of rescue personnel in case of an accident.

Lithium-ion batteries have a limited window of stability regarding temperature and voltage. Overheating may start exothermal reactions that release even more heat which in turn can lead to an accelerated process called a thermal runaway. A thermal runaway can be devastating if it spreads to a complete battery system, releasing large amounts of energy. Such a process could start due to overcharge, overdischarge, mechanical deformation, external heating or an external or internal short circuit, see Figure 1 . The heat generated by any of these events may start exothermal reactions in the battery that in turn could lead to cell venting, fire or explosion.

These risks are well known ${ }^{1-8}$ and are not only associated with the heat and high temperatures that may develop, the emission of harmful or poisonous gases also pose a danger that has been emphasized in literature, ${ }^{9,10}$ but also other gases which can be flammable may be emitted. ${ }^{11-13}$ The reactions during overheating are typically due to the decomposition of the solid electrolyte interphase (SEI) layer, anode and cathode as well as electrolyte decomposition and combustion. ${ }^{5,14}$ These reactions are exothermal. In addition to this separator melting, an endotherm event, may occur. Oxygen may be released at the positive electrode during decomposition; this oxygen can provide the oxidant for the combustion of the electrolyte. Large efforts have been spent on improving the safety of Li-ion cells, e.g. by replacing the cobalt based electrode by lithium iron phosphate ${ }^{15}$ which is more thermally stable and has long life time and high power density but lower energy density. ${ }^{16}$ Another common practice for commercial cells is to use a number of additives to the electrolytes to improve safety, e.g. including fire retarders. ${ }^{17-20}$

Incidents involving lithium-ion batteries have been reported in small as well as large battery systems, see for example Wang et al. ${ }^{21}$

${ }^{\text {zE} E-m a i l: ~ v e g a n @ c h a l m e r s . s e ~}$ and Mikolajczak et al. ${ }^{22}$ Abuse tests of batteries are therefore of prime importance in order to evaluate and improve the level of safety for these types of battery systems. In this article results from abuse tests of commercial Li-ion batteries of different type, chemistry and size are presented to illustrate the problems that may arise under abnormal operating conditions.

\section{Experimental}

Four types of commercial cells were tested; a Samsung 18650-cell, i.e. a cylindrical cell $18 \mathrm{~mm}$ in diameter and $65 \mathrm{~mm}$ long, typically used in laptops; two EiG cells of pouch-type with lithium iron phosphate $\left(\mathrm{LiFePO}_{4}\right)$ cathode, and a carbon-based anode (a newer and an older cell design); a European Batteries cell of pouch-type with lithium iron phosphate cathode and graphite anode. A summary of the cell specifications is provided in Table I. The EiG cells were optimized for power application while the European Batteries cell as well as the laptop cell was optimized for energy applications. All cells were fully charged, $100 \%$ State of Charge (SOC), according to the manufacturer's instructions.

Three types of abuse tests were performed; external heating, overcharge and short circuit tests. All measurements were performed in a similar but not identical condition as described in international test standards for batteries such as FreedomCAR ${ }^{23}$ or SAE J2464. ${ }^{24}$ Cells of different sizes, packaging, chemistries and manufacturers were tested. Most tests were repeated in order to account for the variations between individual cells. The tests presented in this paper are a selection of representative examples of these tests. For the Samsung 18650 cell only results from external heating tests are presented since overcharge and short circuit tests would not be of interest due the built-in cell protection mechanisms in the cell.

External heating test.- In the external heating test, the cells were heated to excessive temperatures in order to examine their thermal stability. This test is sometimes referred to as thermal ramp test. The tested cell was placed inside a thermostatically controlled oven, Binder FED 115. The oven has a microprocessor control and a PT 100 temperature sensor for internal regulation of oven temperature. The oven's internal fan was set on full speed in order to circulate the oven air to obtain a uniform temperature around the tested lithium-ion cell. The cells were placed on one or two bricks in the center of the oven and tested one at a time, see Figure 2. For the pouch cells the oven temperature was first set to $80^{\circ} \mathrm{C}$ and thereafter increased in steps of $10^{\circ} \mathrm{C}$ every $15 \mathrm{~min}$ until either any thermal runaway had occurred or to the maximum temperature of the oven $\left(300^{\circ} \mathrm{C}\right)$. For the 18650 cell the oven was set to the maximum temperature $\left(300^{\circ} \mathrm{C}\right)$ with continuous maximum heating. Both heading procedures were relatively slow. 


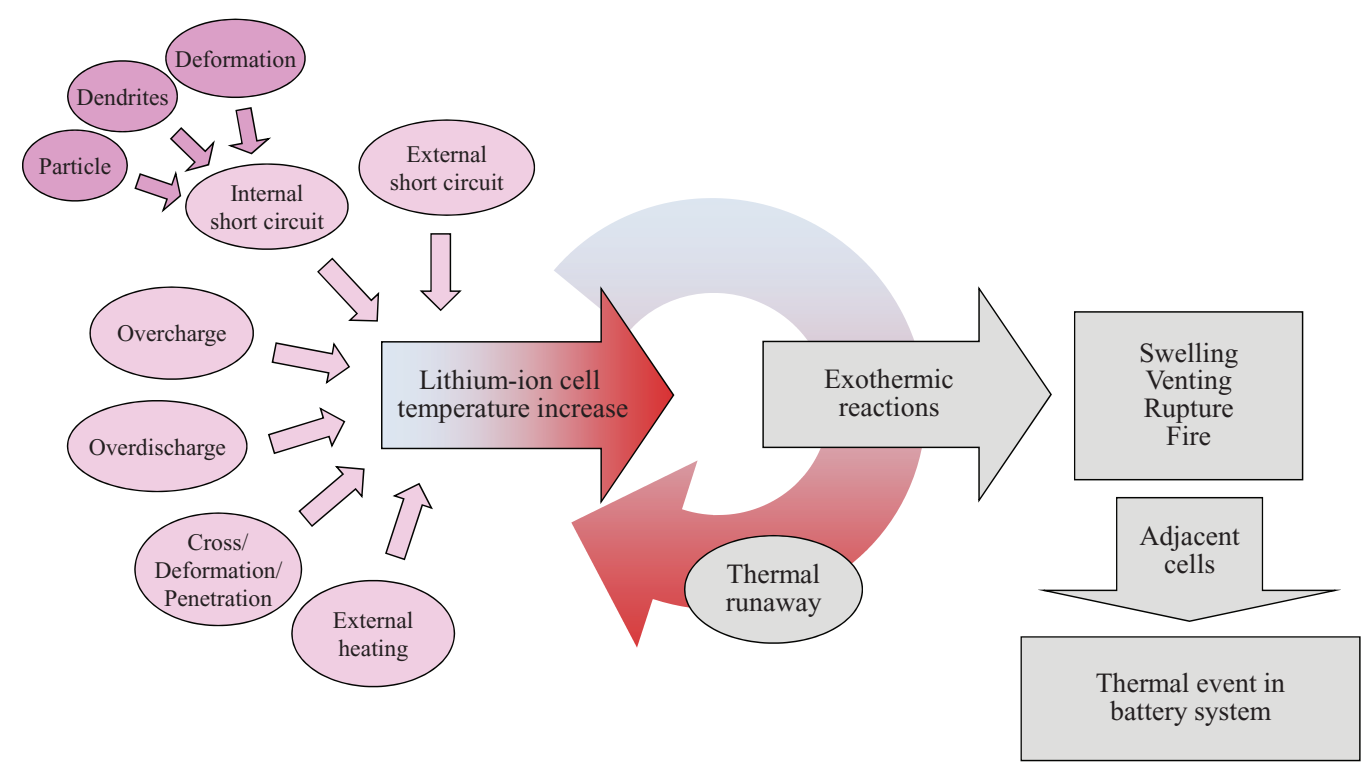

Figure 1. Lithium-ion thermal runaway overview from cell event to potential system event.

Table I. Basic data of tested cells.

\begin{tabular}{|c|c|c|c|}
\hline Cell type & Cell packaging & Nominal voltage $(\mathrm{V})$ & Nominal capacity (Ah) \\
\hline Samsung ICR18650-24F & Cylindrical & 3.6 & 2.4 \\
\hline EiG ePLB-F007H In article referred as "older design" & Pouch & 3.2 & 7 \\
\hline EiG ePLB-F007A In article referred as "newer design" & Pouch & 3.2 & 7 \\
\hline
\end{tabular}

With the continuous heating method it took around $90 \mathrm{~min}$ for the oven to reach $200^{\circ} \mathrm{C}$.

The cell voltage and the cell surface temperature were measured with a sample rate of $1 \mathrm{~Hz}$ with a data logger, Pico Technology ADC24. There were up to five type $\mathrm{K}$ thermocouples evenly distributed on both sides of the cell's surface and one additional thermocouple measuring the oven temperature.

Overcharge test.- In the overcharge test, the lithium-ion cells were abused by being charged beyond their limits. The charger was limited to the preset maximum current of each experiment and up to max 15.3 V. The $7 \mathrm{Ah}$ EiG cell was charged with $70 \mathrm{~A}$ (corresponding to $10 \mathrm{C}$-rate) considering that the cell is optimized for power applica-

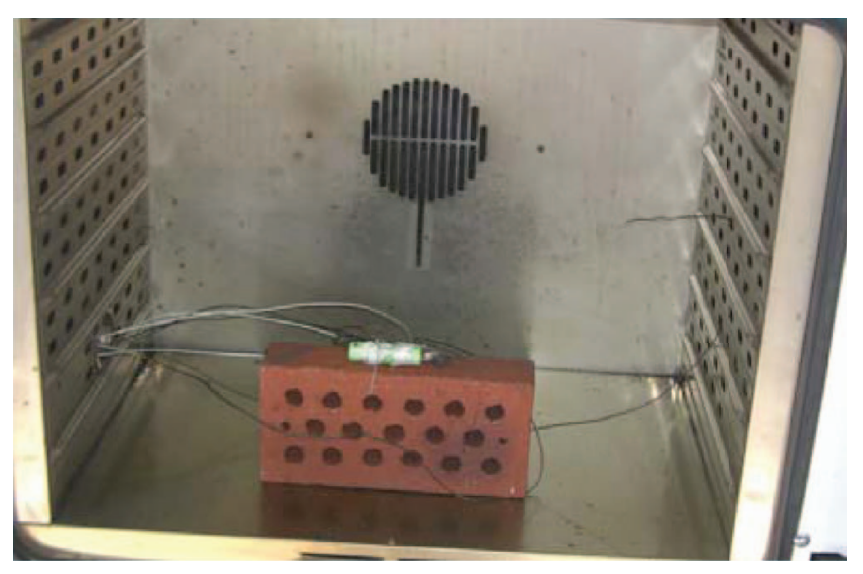

Figure 2. Photo of oven set up, showing a cylindrical 18650 cell fastened onto a brick with steel wire. tions while the 45 Ah European Batteries cell was overcharged with 90 A (corresponding to 2 C-rate) due to its optimization for energy applications. The cell surface temperature was measured with five type K thermocouples; one of the sensors was directly attached to the cell surface while four were so called plate-thermometers, that is a thermocouple attached to a $10 \times 10 \mathrm{~cm}$ metal plate. The platethermometers were distributed around the cell, one directly under the cell, the others placed with an air gap from the cell. The current was measured using a current shunt (accuracy $0.5 \%$ ). Cell voltage, current and temperature were measured with a sample rate of $1 \mathrm{~Hz}$ with a data logger, Pico Technology ADC-24.

Short-circuit test.- EiG and European Batteries cells were short circuited using $50 \mathrm{~mm}^{2}$ copper cables and a high current contactor, Telemecanique LC1F630, with a low internal resistance of $40 \mu \Omega$. The short circuit current was measured by a current core, Hitec $6000 \mathrm{E}$ Topacc 1.0, which can measure currents up to $6000 \mathrm{~A}$. The cell surface temperature was measured with eighteen type $\mathrm{K}$ thermocouples equally distributed on both sides of the cell surface. The cell voltage, current and temperature were measured at $1 \mathrm{~Hz}$ using two data loggers, Pico Technology ADC-24 and Fluke Hydra Series II, as well as by a Tektronix TDS 3034 oscilloscope.

\section{Results}

External heating test.- Figure 3 shows the results of an external heating test on the 18650 cell. At $220^{\circ} \mathrm{C}$, a very rapid temperature increase occurs when the cell catches fire and a pressure wave is observed. The maximum average temperature at the cell surface reaches $743^{\circ} \mathrm{C}$ which is higher than the melting temperature of aluminum, $660^{\circ} \mathrm{C}$. The maximum cell surface temperature measured by a single sensor was $775^{\circ} \mathrm{C}$, the temperature of the cell interior was thus probably even higher. Based on the average surface temperature increase, the corresponding energy released from the thermal runaway 


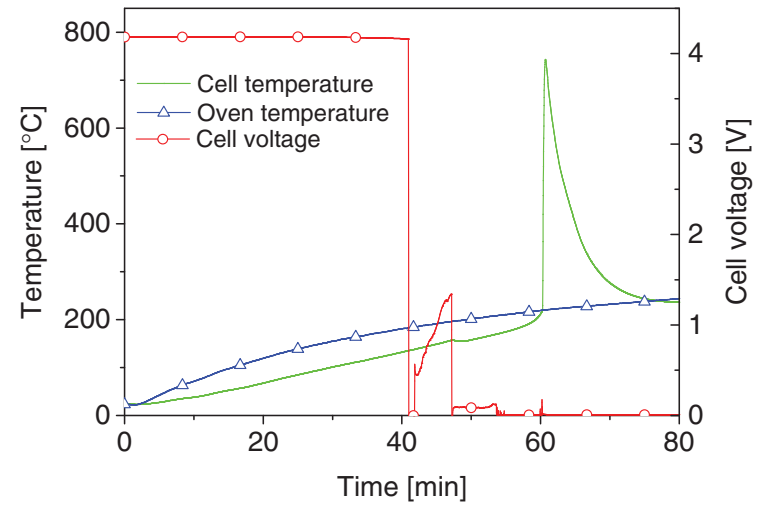

Figure 3. Temperature and cell voltage development during external heating of a Samsung 18650 cell.

can be roughly estimated since the cell is likely to be under adiabatic conditions during the short duration of the thermal runaway, approximately 20 seconds. The specific heat capacity of a complete cell varies between cylindrical and pouch cell packaging and is also dependent on size, energy/power optimization etc. In the estimations we use an approximate value of $700 \mathrm{~J} / \mathrm{kg}^{\circ} \mathrm{C}$ based on published values for different cell types. ${ }^{5,25-29}$ Using the measured temperature increase of $523^{\circ} \mathrm{C}$ the energy released can be estimated to $15.6 \mathrm{~kJ}(4.33 \mathrm{Wh})$. The calculated released energy is thus about half of that of the electrical energy available in the cell, 8.64 Wh. It may also be noted that just prior to the runaway, burning electrolyte is squirting out of the cell seen in Figure 4, which releases energy which is not included in the above value for the energy release calculation. Figure 5 shows the derivative of the average cell surface temperature; the figure shows that the thermal runaway temperature is $220^{\circ} \mathrm{C}$ and that the rate of temperature increase is very high, initially close to $5000^{\circ} \mathrm{C} / \mathrm{min}$.

Cells with lithium iron phosphate (LFP) cathode have an enhanced thermal safety compared to cells with cobalt oxide based cathode. Figure 6 shows the results for two LFP-cells during external heating. The old cell design shows a clear but relatively small thermal runaway event while the new cell design shows no obvious signs of thermal runaway. Actually, a minor exothermic event, hardly visible in Figure 6, can be detected in the same temperature region as the thermal runaway in the old cell design also for the new cell design. The chemical and/or physical changes in the cell design are not known or studied in this report. Complementary experiments where the temperature was continuously increased also resulted in a similar behavior as that in Figure 6 . The time to reach the thermal runaway temperature was approximately 90 minutes for the test using continuous heating and approximately 200 minutes for the test using temperature-ramping.

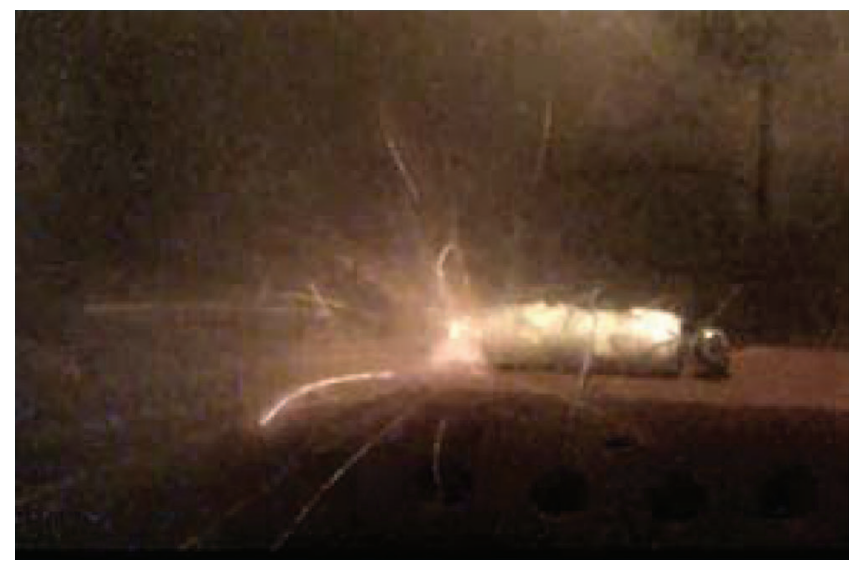

Figure 4. Samsung 18650 cell at the beginning of thermal runaway releasing ignited material.

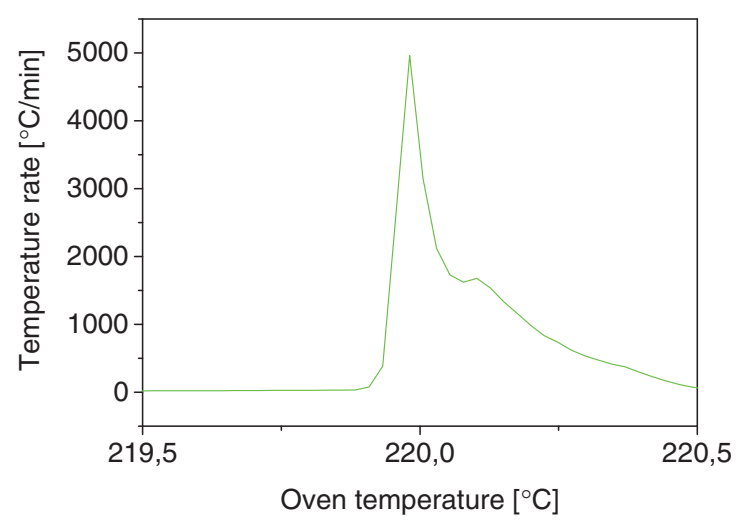

Figure 5. The rate of the cell surface temperature for the Samsung 18650 cell in the temperature region of the thermal runaway peak.

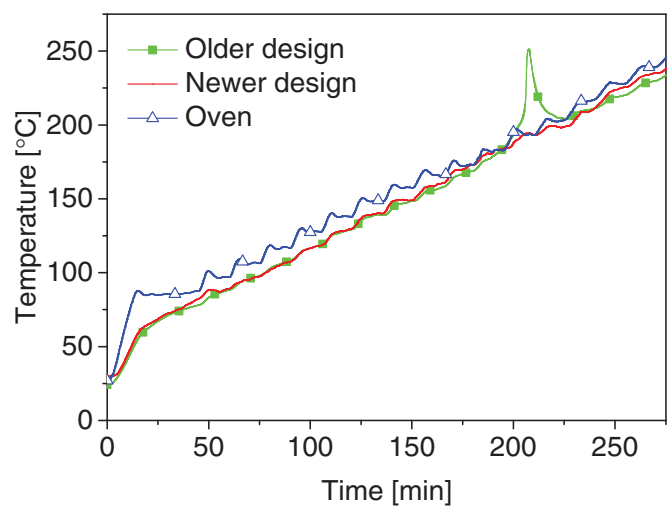

Figure 6. Temperature development during external heating of EiG newer and older cell design.

Figure 7 shows the results of the European Batteries cell during external heating. A moderate thermal runaway is detected also for this LFP-cell, with temperatures reaching well above $300^{\circ} \mathrm{C}$. The runaway temperature was $183^{\circ} \mathrm{C}$ within $\pm 1^{\circ} \mathrm{C}$ for these cells, this value is close to the value observed for the older design $\mathrm{EiG}$ cell, $189^{\circ} \mathrm{C}$. The runaway temperature was thus somewhat lower than for the laptop-type cell. The energy released at the detected thermal runaway estimated using the same method and specific heat capacity value as for the Samsung cell above is also much smaller than for the laptop cell. While the ratio of energy released to the electric energy stored in the fully charged battery is of the order of $50 \%$ for the laptop battery it is

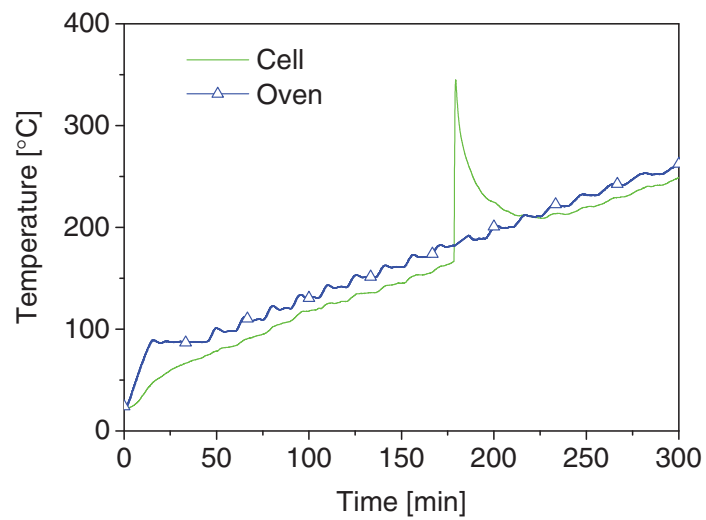

Figure 7. Temperature development during external heating of European Batteries cell. 


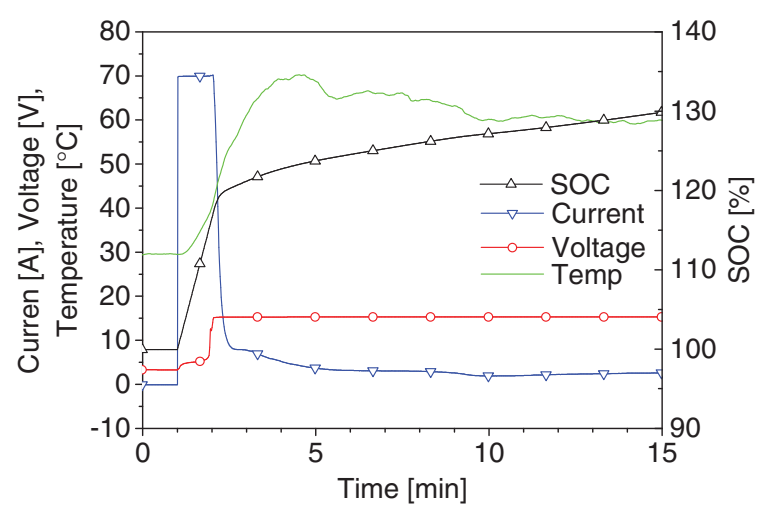

Figure 8. Overcharge of EiG cell of newer design.

between 10 and $30 \%$ for the LFP-type cells that showed a thermal runaway. The rates of temperature increase at the thermal runaway for the LFP-cells were $500^{\circ} \mathrm{C} / \mathrm{min}$ for European Battery cell and $60^{\circ} \mathrm{C} / \mathrm{min}$ for $\mathrm{EiG}$ older design while the rate was not detectable for EiG newer design. The 18650 cell lost $30 \%$ of its weight in the external heating tests while the LFP cells lost between 16-26\%, the EiG new design had the lowest weight loss of $16 \%$.

Overcharge test.- Figure 8 shows the result from an overcharge test of the EiG cell of newer design. The cell surface temperature reached a moderate temperature of $70^{\circ} \mathrm{C}$. An almost negligible weight loss was measured, probably due to minor venting of electrolyte. The overcharge test for one of the European Batteries cells is shown in Figure 9. After approximately 5 minutes of charging at a state of charge level of $115 \%$, the cell suddenly caught fire, as seen in Figure 10. The temperature reached $855^{\circ} \mathrm{C}$ for a sensor placed in the center of the top surface of the cell. During the fire, the top layer of the cell was blown away so the cell temperature presented in Figure 9 may include the temperature of the flames and does not reflect the cell temperature after this event.

The overcharge test on the European Batteries cells was repeated three more times without any occurrence of fire and Figure 11 shows the results of one of the repeated tests. The surface temperature reached a maximum of $79^{\circ} \mathrm{C}$, a value comparable to that of the EiG cell. It may be noted that all overcharged cells were swollen with a thickness increase after the test ranging from 350 to $850 \%$ of the initial thickness.

Short-circuit test.- The results from short circuit tests for EiG cells of both newer and older design are shown in Figure 12. There were no significant differences between the two types of cells. Be-

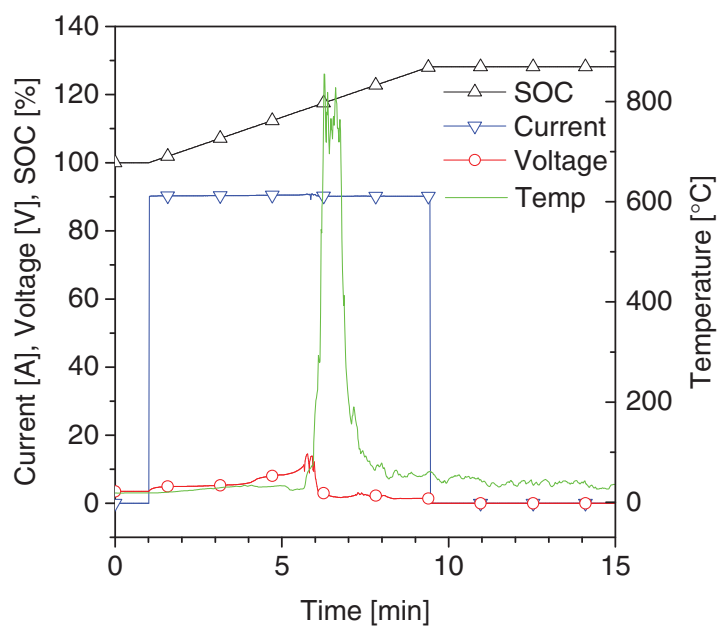

Figure 9. Overcharge of a European Batteries cell resulted in fire, in this case the charger was manually stopped at $9.5 \mathrm{~min}$ due to the fire.

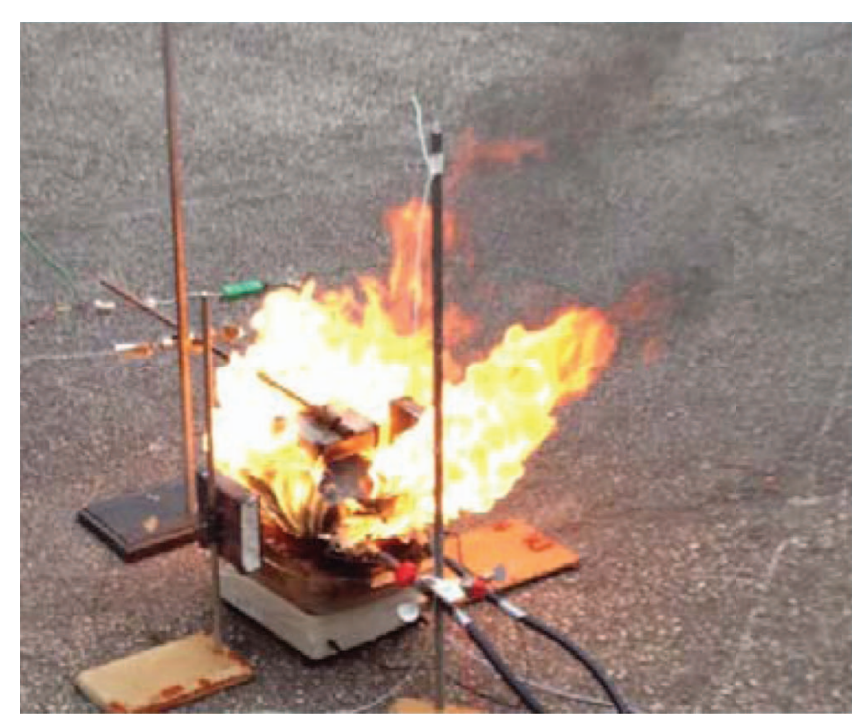

Figure 10. Overcharge of a European Batteries cell resulted in fire.

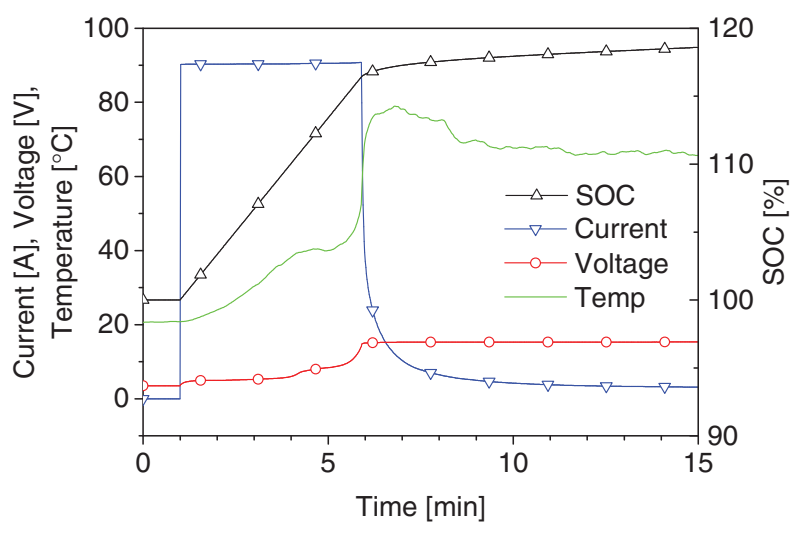

Figure 11. Overcharge of a European Batteries cell that did not result in a fire.

tween 20 and 30 seconds after the start of the short circuit the cell swelled up quickly. The following 2 minutes the cell vented (with no visual smoke) and swelling decreased considerably. The following 5 minutes the cell contracted further to a thickness close to that of the untested cell. The peak current reached almost 900 A which corresponds to a discharge rate of $128 \mathrm{C}$. The maximum cell surface

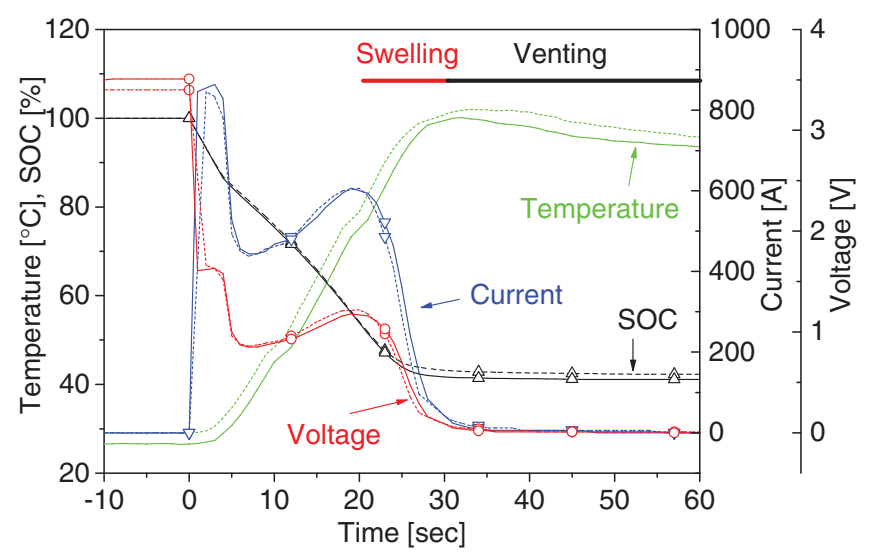

Figure 12. Short circuit of EiG cell of newer design (dashed lines) and EiG of older design (solid lines). 

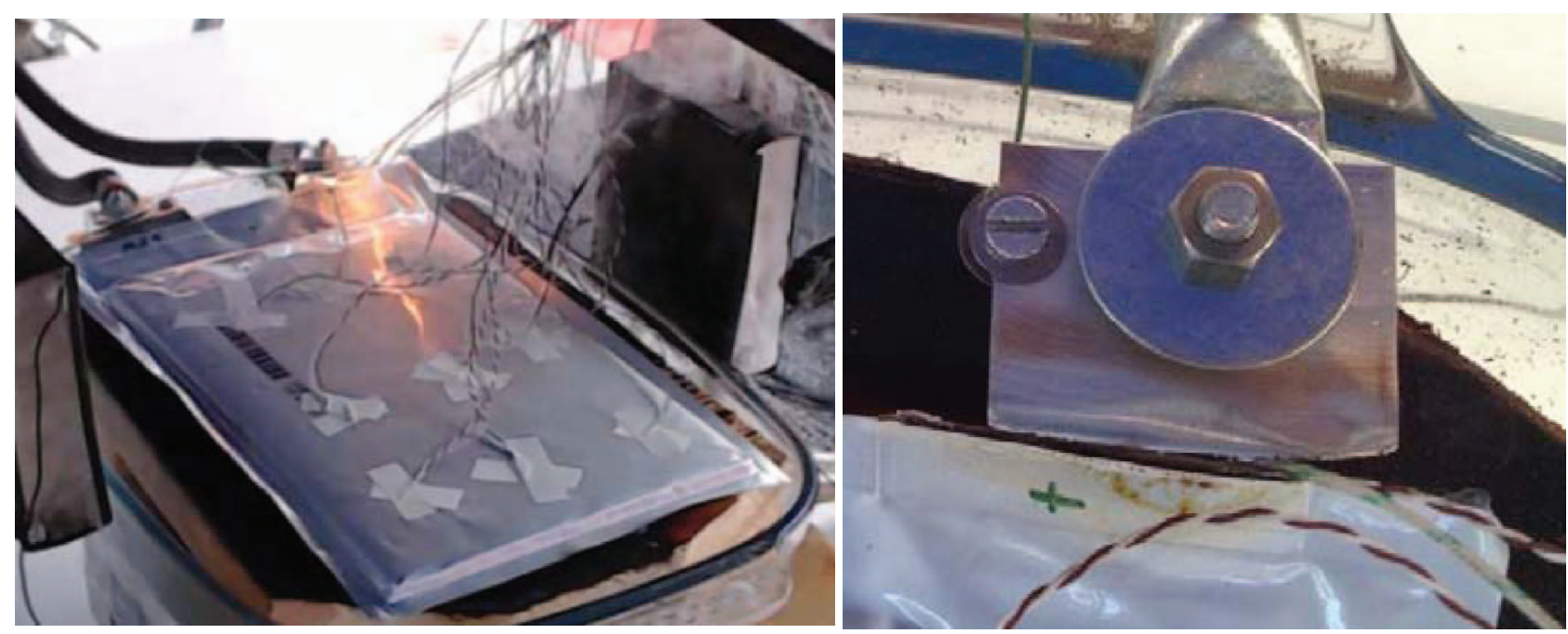

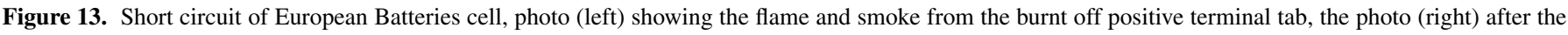
test shows the burnt off tab.

temperature was about $100^{\circ} \mathrm{C}$ and both types of cells were discharged to about $43 \%$ SOC.

In the short circuit test of the European Batteries cell the positive tab of the cell burnt off, which stopped the short circuit current, see Figure 13. The current just before this event was $1084 \mathrm{~A}$ and due to the very short time for the short circuit the cell temperature and SOC changed very little, less than $6^{\circ} \mathrm{C}$ and $4 \%$ respectively.

\section{Discussion}

When the Samsung 18650 laptop cell was exposed to external heat, the open circuit voltage remained stable until about $135^{\circ} \mathrm{C}$, measured on the cell surface, as seen in Figure 3, then it falls abruptly. The melting points of typical shutdown separator materials, polyethylene and polypropylene, are about 130 and $165^{\circ} \mathrm{C}$, the measured values are thus reasonably close to these values, where the final voltage drop occurs at about $158^{\circ} \mathrm{C}$. The difference may be due to a delay in the temperature measurement due to the slow heat transfer in the interior of the cell. The runaway temperature, $220^{\circ} \mathrm{C}$, and the temperature increase during the thermal runaway, $532^{\circ} \mathrm{C}$, is in the same order as reported in our previous study. ${ }^{30}$ The rate of temperature increase in the initial phase of the thermal runaway is extremely high, close to $5000^{\circ} \mathrm{C} / \mathrm{min}$. Jhu et al. ${ }^{28}$ found for a similar cell a peak value of about $37000^{\circ} \mathrm{C} / \mathrm{min}$ with a more sensitive technique, and in another study by Jhu et al. ${ }^{29}$ temperate rates beyond $70000^{\circ} \mathrm{C} / \mathrm{min}$ were found. The state of charge can have a strong influence on the cell behavior during abuse situations and the influence may vary with different types of abuse. Jhu et al. ${ }^{28,29}$ and Doughty et al. ${ }^{17}$ showed that lower SOC gives lower energy release during external heating.

A comparison of the results of the external heating tests for the 18650 laptop cell (Figure 3) and the LFP-cells (Figure 6 and Figure 7) shows that the behavior is much less dramatic for the LFP-cells. Two of the three LFP-cells still go into thermal runaway but the energy released is much less than that from a cell with cobalt-based cathode. This is well-known from other studies ${ }^{2,13,20,31-36}$ and attributed to the stability of the olivine structure of $\mathrm{LiFePO}_{4}$. The electrode influence on the thermal stability of a LFP-cell is therefore dominated by the anode material. Swelling and venting occurred for all pouch-type cells while the laptop cell vented with a rapid release of gas, accompanied by a pressure wave and immediately followed by fire.

The runaway temperature for the LFP-cells was lower than for the laptop cell, $189^{\circ} \mathrm{C}$ for the $\mathrm{EiG}$ older design and $183^{\circ} \mathrm{C}$ for the European Batteries cell. The thermal runway in the external heating test for the new design of EiG is significantly reduced compared to that of the older design. It may be noted that the EiG cell is designed to target electrified vehicles in the automotive sector and is currently in use there. The rates of temperate increase at runaway differ considerably for the different cells; $5000^{\circ} \mathrm{C} / \mathrm{min}$ for the Samsung laptop cell, $500^{\circ} \mathrm{C} / \mathrm{min}$ for European Battery cell and $60^{\circ} \mathrm{C} / \mathrm{min}$ for $\mathrm{EiG}$ older design. This highlights the large differences for Li-ion cells and particularly underlines the importance of thermal stability.

Cell venting is an important safety factor to protect a Li-ion battery from reaching too high pressure, especially in the case of cylindrical or hard prismatic cell packaging. In fact, cell manufacturers may include so called shutdown additives in the electrolyte in order to activate cell venting at a pre-designed stage by gas generation from polymerizing of the additive molecules, before the cell reaches extreme conditions. ${ }^{20}$ Upon heating of a cell, ventilation is also unavoidable since the electrolyte typically consists of a Li-salt dissolved in volatile organic solvents. Even in cases when fire or explosion does not occur, emitted flammable and toxic gas can be a serious problem as mentioned in the introduction.

Abuse by overcharging and external heating adds energy to the system due to the input of electric power or heat, while in a short circuit test no energy is added to the cell. Therefore, the overcharge and external heating test can theoretically be seen as a more severe abuse due to the addition of external energy to the cell. In the overcharge tests presented the additional charged energy is between $20-30 \%$ in terms of battery capacity. The energy released in the external heating tests presented in this paper is calculated based on the change of the cell surface temperature and are of the order of $50 \%$ or less of the electrical energy within the cell. Those values do not represent the total energy release and neither the possible maximum energy release during the most severe abuse situations when the cell materials are allowed to fully combust. During the external heating, part of the electrolyte, and particularly low boiling components (e.g. dimethyl carbonate), can evaporate due to venting and cell opening. However, some electrolyte is still present since thermal runaway does occur. For example, for the 18650 cell, electrolyte is squirting out of the cell prior to the thermal runaway as seen in Figure 4, releasing energy which is not included in the calculations. Besides, several other parameters also affect the results e.g. abuse test methods, cell chemistry, capacity size, cell design and cell venting characteristics. Values typically found in the literature show a released energy of 2-3 times the electrical energy. ${ }^{1,38}$ The results presented in this article are lower presumably due to the reasons discussed above. However, the energy release, $15.6 \mathrm{~kJ}$, of the thermal runaway for the 18650 cell in the external heating test can be compared to $19.2 \mathrm{~kJ}$ measured for a similar 18650 cell. $^{28}$

$10 \mathrm{C}$-rate overcharge tests of the EiG newer design did not result in a thermal runaway and the peak surface temperature reached 
a moderate $79^{\circ} \mathrm{C}$. A similar result was obtained for one of the European Batteries cells, seen in Figure 11. However, one of the European Batteries cells that was overcharged ignited with a resulting fire. This behavior was not reproduced in three other tests. Excluding the ignited cell, no thermal runaway could be detected even though all cells were heavily affected by large swelling and venting. Hund and Ingersoll ${ }^{38}$ studied $1 \mathrm{C}$-rate overcharge of LiFeBatt $10 \mathrm{Ah}$ LFP cells which resulted in a significantly higher temperature of $160^{\circ} \mathrm{C}$ but no fire or sparks. He et al. ${ }^{39}$ used 2 Ah LFP cells and found a temperature peak of $90^{\circ} \mathrm{C}$ without fire during $1 \mathrm{C}$-rate overcharging. The incident of the fire in our test is interesting but we can only speculate on the reason. It could be a bad cell due to errors in the manufacturing process or induced by some small variety in the test setup. An event like this in the field could be referred to as a field failure, but field failures rarely happens on cell-level, the probability is typically less than $1 \mathrm{ppm} .^{21,22}$ For an overcharge situation to occur in a battery system a failure of the Battery Management System (BMS) is required allowing the cell to be charged above it limits. Secondly, as we have seen above, the cell itself does not necessarily go into thermal runaway because it is overcharged. Studies have, however, shown that LFP-cells have a smaller margin with respect to the amount of overcharged capacity compared to other common Li-chemistries, although the exothermal response for LFP is significantly lower. ${ }^{2}$

The tested large-sized LFP pouch automotive cells have low internal resistance, enabling high short circuit currents known from other studies. ${ }^{40}$ The short circuit current of the EiG cells was close to $900 \mathrm{~A}$, corresponding to a $128 \mathrm{C}$-rate. These cells are power optimized and capable of delivering 20-30 C-rate in normal use. The short circuit current for the six times larger capacity European Batteries cell is close to 1100 A, i.e. a 24 C-rate. The European Batteries cell is energy optimized and made to deliver up to $4 \mathrm{C}$-rate in normal use. The cell voltage seen in Figure 12 drops quickly due to the short circuit, but does not reach $0 \mathrm{~V}$ instantly even if it is a hard short circuit with low connection resistance. The current curve in Figure 12 quickly rises and then falls to about half the value and then increases again. This behavior could be explained by the fact that the extreme current cannot be sustained due to limitations of the transport process of the lithium ion in the cell resulting in a current drop, while the cell is quickly heated due to the ohmic losses. The increased temperature finally enables a higher transportation of lithium ions resulting in an increased current. The time frame for these phases is less than $30 \mathrm{sec}$ onds as seen in Figure 12. No thermal runaway is observed, however the cell temperature increases fast during a short period of time.

The short circuit test of the European Batteries cell resulted in that the positive terminal tab burnt off as seen in Figure 13 which stopped the short circuit. In one perspective this can potentially be seen as positive for the safety since the tab functioned as a "fuse" that stopped the short circuit at an early stage. However the flame can be a potential source of ignition of e.g. vented and flammable battery gases or other easily ignitable materials inside a battery system.

Lithium-ion cells can be equipped with a variety of reversible and irreversible safety mechanisms. ${ }^{41}$ The 18650 cells typically have protection for short circuit, by the use of for example CID (current interrupture device) and PTC (positive temperature coefficient), the latter causing the cell resistance to increase rapidly at increased temperature reducing the current going through the cell. Many of these safety mechanisms were developed specifically for the Li-ion consumer battery. The use of Li-ion batteries in other applications such as within automotive give rise to more and different demands on the safety as well as other aspects, e.g. cost, life time, energy and power density. The environmental conditions in automotive applications are different to those in consumer products; vibrations, extreme temperatures and varying humidity can be challenging. The risks involved in case of electric vehicle crash deformations must also be taken into consideration. In the automotive industry large capacity cells are required and typically hundreds of these are connected in series. Safety mechanisms within the cell used in commercial Li-ion battery systems do not always give the same protection in e.g. automotive applications. A first example is the shutdown separator which can give an increased safety for some cell abuse situations. However, the use of shutdown separators in a large battery pack with higher voltage due to hundreds of cells connected in series might not give the same safety due to e.g. voltage breakdown of the separator. ${ }^{42,43}$ A second example is the PTC which has a relative low voltage tolerance in cell-strings, potentially as low as $30 \mathrm{~V}$, which can result in spontaneous ignition in case of overvoltage. ${ }^{44}$ Besides the safety concern the PTC also add parasitic resistance in a large battery pack. A third example is the CID which cannot offer the same safety in case of higher voltage systems. ${ }^{44}$

The battery module design as well as the rate of energy release and the total energy release from a thermal runaway in one cell determines if neighboring cells are effected or not. From a safety perspective it is essential to minimize the probability for a thermal event to occur but also to minimize the consequences of such an event and prevent damage to neighboring cells, avoiding the potential propagation of a thermal runaway from cell to system-level as shown in Figure 1.

\section{Conclusions}

The abuse tests conducted on various types of Li-ion cells give valuable information regarding diverse aspects of the cell safety. Risks associated with thermal runaway situations; fire, smoke and gas emissions are especially important for the use of Li-ion batteries in automotive applications. The external heating test of the 18650 laptop cell resulted in a rapid thermal runaway accompanied with a pressure wave and immediate fire. In large battery packs using multiple cells in series and/or parallel the effect of a propagation scenario in thus a concern. Safer chemistries like the LFP-cells are in general significantly less energetic. Nevertheless our results show that LFP-cells can still go into a thermal runaway event even though the tested LFP cells showed various results. During external heating up to $300^{\circ} \mathrm{C} \mathrm{a}$ LFP-cell with a newer design did not show any substantial thermal runaway while older design LFP cells showed a moderate thermal runaway. Overcharge of the newer designed LFP-cell did not result in thermal runaway either. However, overcharge of another LFP pouch cell did result in a fire, even if that event could not be reproduced in this study.

The energy released during a thermal runaway based on the results reported above for a 18650 cobalt-based cell can be used to estimate how much energy may be released in a thermal runaway of a $300 \mathrm{~kg}$ battery system for an electric vehicle. The answer is perhaps somewhat surprising, the calculation shows that the energy released could be in the order of $70 \mathrm{MJ}$, corresponding to the combustion of about 2 liters of gasoline. However, our estimate is low, as described above, and using the highest value reported earlier one can expect a value up to six times that calculated here. This is still considering the battery type that has the largest energy release while other more safe chemistries, e.g. LFP will have lower values. The presented results thus show that although the safety aspects of Li-ion batteries are still a concern, the safety is improving with safer chemical components and design improvements.

\section{Acknowledgments}

The authors thank the Swedish Energy Agency and the FFIprogram for its support.

\section{References}

1. G. G. Eshetu, S. Grugeon, S. Laurelle, S. Boyanov, A. Lecocq, J.-P. Bertrand, and G. Marlair, Phys. Chem. Chem. Phys., 15, 9145 (2013).

2. D. Doughty and E. P. Roth, The Electrochem. Soc. Interface: summer 2012, 37 (2012).

3. E. P. Roth and C. J. Orendorff, The Electrochem. Soc. Interface: summer 2012, 45 (2012).

4. D. Lisbona and T. Snee, Process Safety and Environmental Protection, 89, 434 (2011).

5. R. Spotnitz and J. Franklin, J. of Power Sources, 113, 81 (2003).

6. P. Biensan, B. Simon, J. P. Pérès, A. de Guibert, M. Broussely, J. M. Bodet, and F. Perton, J. of Power Sources, 81-82, 906 (1999). 
7. F. Larsson, P. Andersson and B.-E. Mellander, "Are electric vehicles safer than combustion engine vehicles?", Chapter 4 in Systems perspectives on Electromobility, edited by B. Sandén, Chalmers University of Technology, Goteborg, Sweden, ISBN 978-91-980973-1-3, p. 31 (2013).

8. Z. J. Zhang, P. Ramadass, and W. Fang, "Safety of lithium-ion batteries", Chapter 18 in Lithium-Ion Batteries: Advances and Applications, edited by G. Pistoia, Elsevier, Amsterdam, The Netherlands, p. 409 (2014).

9. A. Hammami, N. Raymond, and M. Armand, Nature, 424, 635 (2003)

10. H. Yang, G. V. Zhuang, and P. N. Ross Jr, J. of Power Sources, 161, 573 (2006)

11. T. Ohsaki, T. Kishi, T. Kuboki, N. Takami, N. Shimura, Y. Sato, M. Sekino, and A. Satoh, J. of Power Sources, 146, 97 (2005).

12. D. P. Abraham, E. P. Roth, R. Kostecki, K. McCarthy, S. MacLaren, and D. H. Doughty, J. of Power Sources, 161, 648 (2006)

13. E. P. Roth, ECS Trans., 11(19), 19 (2008).

14. C. Arbizzani, G. Gabrielli, and M. Mastragostino, J. of Power Sources, 196, 4801 (2011).

15. A. K. Padhi, K. S. Nanjundaswarmy, and J. B. Goodenough, J. Electrochem. Soc., 144, 1188 (1997)

16. K. Zaghib, A. Guerfi, P. Hovington, A. Vijh, M. Trudeau, A. Mauger, J. B. Goodenough, and C. M. Julien, J. of Power Sources, 232, 357 (2013).

17. D. H. Doughty, E. P. Roth, C. C. Craft, G. Nagasubramanian, G. Henriksen, and K. Amine, J. of Power Sources, 146, 116 (2005).

18. S. S. Zhang, J. of Power Sources, 162, 1379 (2006).

19. G. Nagasubramanian and K. Fenton, Electrochimica Acta, 101, 3 (2013).

20. K. Zaghib, J. Dubé, A. Dallaire, K. Galoustov, A. Guerfi, M. Ramanathan, A. Benmayza, J. Prakash, A. Mauger, and C. M Julien, "Lithium-ion cell components and their effect on high-power battery safety", Chapter 19 in Lithium-Ion Batteries: Advances and Applications, edited by G. Pistoia, Elsevier, Amsterdam, The Netherlands, p. 437 (2014).

21. Q. Wang, P. Ping, X. Zhao, G. Chu, J. Sun, and C. Chen, J. of Power Sources, 208, 210 (2012).

22. C. Mikolajczak, M. Kahn, K. White, and R. T. Long, "Lithium-ion batteries hazard and use assessment", Fire Protection Research Foundation, Quincy, MA, USA, Doc no 1100034.000 A0F0 0711 CM01 (2011).

23. D. H. Doughty and C. C. Crafts, "FreedomCAR electrical energy storage system abuse test manual for electric and hybrid electric vehicle applications", Sandia report SAND2005-3123, Sandia National Laboratories, USA (2006).

24. D. Doughty, "SAE J2464 Electric and hybrid electric vehicle rechargeable energy storage system (RESS) safety and abuse testing procedure", SAE Technical Pape 2010-01-1077, (2010)
25. L. Fan, J. M. Khodadadi, and A. A. Pesaran, J of Power Sources, 238, 301 (2013).

26. J. Yi, U. S. Kim, C. B. Shin, T. Han, and S. Park, J. of the Electrochem. Soc., 160(3), A437 (2013).

27. W. Wu, X. Xiao, and X. Huang, Electrochimica Acta 83, 227 (2012)

28. C.-Y. Jhu, Y.-W. Wang, C.-Y. Wen, C.-C. Chiang, and C.-M. Shu, J. Therm. Anal. Calorim., 106, 159 (2011)

29. C.-Y. Jhu, Y.-W. Wang, C.-M. Shu, J.-C. Chang, and H.-C. Wu, J. of Hazardous Materials, 192, 99 (2011).

30. F. Larsson and B.-E. Mellander, Conference proceedings of Fires in vehicles (FIVE) 2012, edited by P. Andersson and B. Sundstrom, SP Technical Research Institute of Sweden, Sweden, p. 303 (2012).

31. M. Takahaski, S. Tobishima, K. Takei, and Y. Sakurai, Solid State Ionics, 148, 283 (2002).

32. A. Yamada, S. C. Chung, and K. Hinokuma, J. of the Electrochem. Soc., 148(3), A224 (2001).

33. H. Joachin, T. D. Kaun, K. Zaghib, and J. Prakash, J. of the Electrochem. Soc., 156(6), A401 (2009).

34. K. Zaghib, J. Dubé, A. Dallaire, K. Galoustov, A. Guerfi, M. Ramanathan, A. Benmayza, J. Prakash, A. Mauger, and C. M. Julien, J. of Power Sources, 219, 36 (2012).

35. G. Chen and T. J. Richardson, J. of the Electrochem. Soc., 156(9), A756 (2009).

36. G. Chen and T. J. Richardson, J. of Power Sources, 195, 1221 (2010).

37. E. P. Roth, "Lithium ion cell and battery safety", Tutorials E in Conference proceedings in Advanced Automotive Battery Conference (AABC), AABC Europe 2011, Mainz, Germany (2011).

38. T. D. Hund and D. Ingersoll, "Selected test results from the LiFeBatt iron phosphate Li-ion battery", Sandia report SAND2008-5583, Sandia National Laboratories, USA (2008).

39. Y.-B He, G.-W. Ling, Z.-Y. Tang, Q.-S. Song, Q.-H. Yang, W. Chen, W. Lv, Y.-J. Su, and Q. Xu, J. Solid State Electrochem., 14, 751 (2010).

40. F. V. Conte, P. Gollob, and H. Lacher, World Electric Vehicle J., 3, 1 (2009).

41. P. G. Balakrishnan, R. Ramesh, and T. P. Kumar, J. of Power Sources, 155, 401 (2006).

42. E. P. Roth, D. H. Doughty, and D. L. Pile, J. of Power Sources, 174, 579 (2007)

43. C. J. Orendorff, The Electrochem. Soc. Interface: summer 2012, 61 (2012).

44. J. Jeevarajan, "Safety of commercial lithium-ion cells and batteries", Chapter 17 in Lithium-Ion Batteries: Advances and Applications, edited by G. Pistoia, Elsevier, Amsterdam, The Netherlands, p. 387 (2014). 